\title{
37. PRELIMINARY RESULTS, ORGANIC GEOCHEMICAL INVESTIGATION OF BLACK SEA SEDIMENTS: DEEP SEA DRILLING PROJECT LEG 42B
}

\author{
Donald F. Anders, George E. Claypool, Sister Carlos M. Lubeck, and John M. Patterson, \\ U.S. Geological Survey, Box 25046, Denver Federal Center, Denver, Colorado
}

\section{INTRODUCTION}

Black Sea sediments of Pleistocene age cored during DSDP Leg 42B were deposited mostly under lacustrine conditions. The shipboard summary of this leg mentions certain similarities between these Black Sea sediments and those of the Eocene Green River Formation of Wyoming, Colorado, and Utah. A suite of samples has been analyzed in order to test for organic geochemical similarities. It is believed that the results provide a useful analog for lacustrine sediments of Tertiary age in the western United States.

The latitude, longitude, water depth, and depth of penetration of each drilling site is summarized in Table 1. The general stratigraphy of the penetrated section is shown in Figure 1.

\section{ANALYTICAL PROCEDURES}

Organic carbon: Samples of 0.25 to $0.75 \mathrm{~g}$ were treated with 1 to $3 \mathrm{ml}$ conc. $\mathrm{HCl}$ in LECO filtering crucibles. The solution was evaporated to dryness to remove excess $\mathrm{HCl}$ and to promote precipitation of organic material possibly solubilized in the acid treatment. The crucibles were lightly washed with distilled water under suction, and then oven dried at $105^{\circ} \mathrm{C}$. After addition of combustion accelerators, the samples were burned in a stream of oxygen. The $\mathrm{CO}_{2}$ produced was measured gravimetrically in ascaritemagnesium perchlorate absorption bulbs.

Thermal analysis: The MP-3 thermal chromatograph was used following the general procedure described by Claypool and Reed (1976). About 0.05 to $0.15 \mathrm{~g}$ of freeze-dried sediment was heated at a rate of temperature increase of $40^{\circ} \mathrm{C} / \mathrm{min}$, from $30^{\circ}$ to $800^{\circ} \mathrm{C}$ in a stream of helium. Organic-carbon-containing compounds evolved as a function of temperature were transported from the furnace by a heated line $\left(250^{\circ} \mathrm{C}\right)$ and monitored by a hydrogen flame ionization detector. The total millivolt signal was integrated over the time of the analysis, normalized by the sample weight, and related to the quantity of volatile organic matter evolved from the rock by empirical calibration curves.

Solvent extraction and column chromatography: Samples of freeze $=$ dried sediment, weighing from 63 to $104 \mathrm{~g}$ were disaggregated and lightly ground in a porcelain mortar and pestle, then extracted with chloroform in a soxhlet apparatus. The chloroformsoluble bitumen was isolated by distillation of the chloroform under reduced pressure, followed by evaporation under nitrogen to an arbitrarily defined
TABLE 1

Location, Water Depth, and Depths of Penetration for Black Sea Drilling Sites, Leg 42B

\begin{tabular}{lllcc}
\hline Site & Latitude & Longtitude & $\begin{array}{c}\text { Water } \\
\text { Depth } \\
(\mathrm{m})\end{array}$ & $\begin{array}{c}\text { Depth of } \\
\text { Penetration } \\
(\mathrm{m})\end{array}$ \\
\hline 379 & $43^{\circ} 00.29^{\prime}$ & $36^{\circ} 00.68^{\prime}$ & 2172 & 624 \\
$380 / 380 \mathrm{~A}$ & $42^{\circ} 06^{\prime}$ & $29^{\circ} 37^{\prime}$ & 2115 & 1074 \\
381 & $41^{\circ} 40.25^{\prime}$ & $29^{\circ} 24.96^{\prime}$ & 1751 & 503 \\
\hline
\end{tabular}

constant weight (weight loss after 15-minute evaporation period is less than $0.2 \mathrm{mg}$ or $5 \%$ of previous net weight). The total bitumen, or an aliquot, was

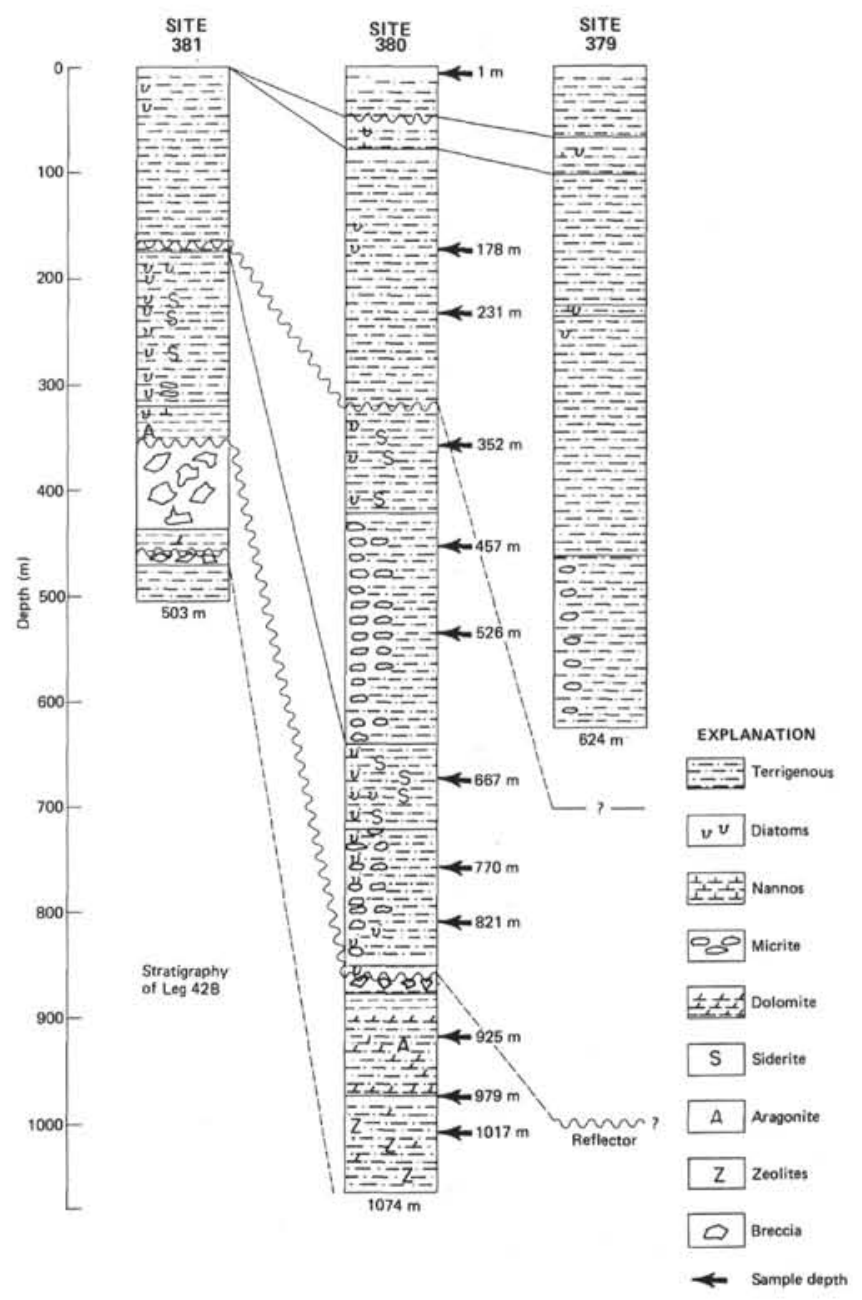

Figure 1. General stratigraphy of Black Sea sediments, Leg $42 B$ drilling sites. 
fractionated over silica gel into heptane, benzene, and benzene-methanol eluates, which were isolated and weighed using the same procedure applied to the bitumen.

Gas chromatography of heptane eluate: The heptane eluate of each sample was redissolved in an amount of heptane sufficient to give a concentration of about 10 $\mathrm{mg} / \mathrm{ml} .2 .4 \mu \mathrm{l}$ of each sample was injected by a Varian 8000 automatic sampling device and analyzed in a Varian 2800 on $2.0 \mathrm{~mm} \times 1.8$ meter columns packed with $3.0 \%$ GCSE-30 on 100-120 mesh Gas Chrom Q, $\mathrm{He}$ flow was $40 \mathrm{ml} / \mathrm{min}$. Column temperature was $80^{\circ} \mathrm{C}$ at injection and was programmed to rise $12^{\circ} \mathrm{C} / \mathrm{min}$ for 10 minutes, then $10^{\circ} \mathrm{C} / \mathrm{min}$ for 12 minutes to a final temperature of $320^{\circ} \mathrm{C}$.

Gas chromatography-mass spectrometry of heptane eluate: Each of the heptane eluates was injected into another gas chromatograph (HP5710A) connected by a $2.3 \mathrm{~cm}$ Watson Biemann Helium separator to a Hitachi RMU-6H mass spectrometer equipped with an AEI DS-50 data system. Prior to enrichment, the material was separated by gas chromatography on a stainless steel 2 meter $\times 3.2 \mathrm{~mm}$ ID column packed with $3 \%$ SE30 on $80-100$ mesh Gas Chrom Q $\left(80-300^{\circ} \mathrm{C}\right.$ (a) $10^{\circ} \mathrm{C} / \mathrm{min}$ ). The Helium flow rate of $30 \mathrm{cc} / \mathrm{min}$ was split at the exit of the column, allowing $20 \mathrm{cc} / \mathrm{min}$ to go to the Helium separator (maintained at $300^{\circ} \mathrm{C}$ ) and 10 $\mathrm{cc} / \mathrm{min}$ to go to the FID detector. The ion source temperature was approximately $220^{\circ} \mathrm{C}$. The ionizing voltage was $70 \mathrm{eV}$ with a filament emission of $80 \mu \mathrm{A}$. Scan rate was $3 \mathrm{sec} /$ decade for the mass range 28-560 AMU. Spectra were recorded on an AEI DS50 data system. Background spectra were also recorded. PFK (perfluorokersene) was used as mass marker. All reported spectra have had the background subtracted and have been normalized to the most intense fragment ion above $\mathrm{m} / \mathrm{e} 100$.

\section{RESULTS AND DISCUSSION}

\section{Organic Carbon and Thermal Analysis}

Sixty-seven samples from Leg 42B were analyzed for organic carbon by combustion of an acid-insoluable residue. These results are given in Table 2 . Thirty-four of these samples were also analyzed by the thermal analysis-pyrolysis technique. The integrated flame ionization response is converted to pyrolytic hydrocarbon yield by an empirical calibration curve and is also summarized in Table 2 .

Figure 2 is a plot of organic carbon versus thermal analysis (pyrolysis) hydrocarbon yield. Also shown on Figure 2 for comparison are results from five black shale samples of Aptian and Albian Age from Hole 391, Leg 44. Figure 2 illustrates that there is a consistent non-linear relationship between the yield of volatile pyrolysis products and the amount of organic carbon. The slope of this curved line is apparently a charatceristic of the type of organic matter deposited and preserved in a particular sedimentary environment. In the case of Black Sea sediments, one possible interpretation of the relationship shown in Figure 2 is that there is a mixture of two dominant types of organic
TABLE 2

Organic Carbon and Pyrolytic Hydrocarbon Yield Leg 42B

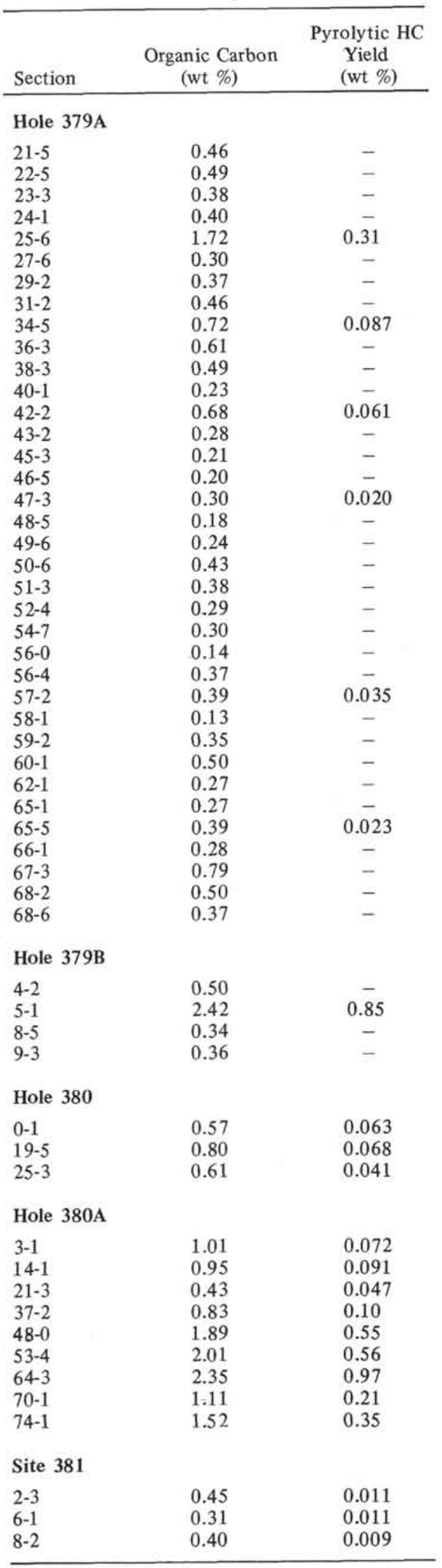


TABLE 2 - Continued

\begin{tabular}{ccc}
\hline & $\begin{array}{c}\text { Pyrolytic HC } \\
\text { Yield }\end{array}$ \\
Section & (wt \%) & (wt \%) \\
\hline
\end{tabular}

Site 381 - Continued

\begin{tabular}{lll}
$9-0$ & 0.78 & 0.034 \\
$12-3$ & 0.48 & 0.014 \\
$13-2$ & 0.73 & 0.088 \\
$15-1$ & 0.63 & 0.040 \\
$16-3$ & 0.51 & 0.023 \\
$17-2$ & 0.61 & 0.043 \\
$23-6$ & 1.37 & 0.22 \\
$26-1$ & 1.59 & 0.47 \\
$33-5$ & 1.03 & 0.37 \\
$37-3$ & 5.32 & 3.18 \\
$54-0$ & 1.27 & 0.14 \\
$54-5$ & 1.54 & 0.19 \\
\hline
\end{tabular}

${ }^{\mathrm{a}}$ Leaders (-) indicate sample was not analyzed for pyrolytic hydrocarbon.

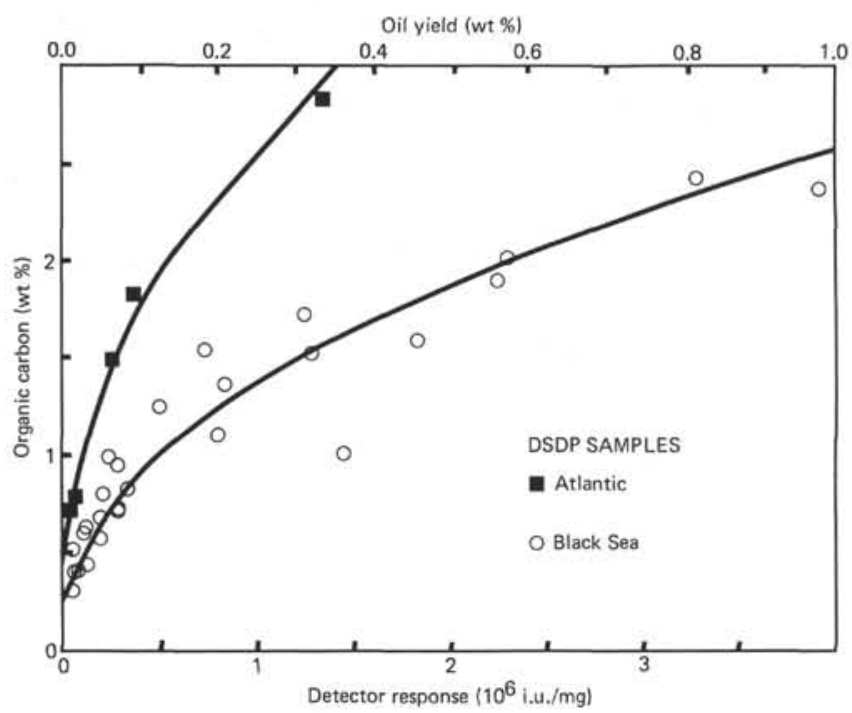

Figure 2. Organic carbon content versus pyrolytic hydroyield.

matter. The sediments appear to contain a constant minimum of about $0.4 \%$ organic carbon which is refractory and yields little or no volatile product upon pyrolysis. This component may be recycled kerogen or charcoal. Added to this refractory carbon is a variable component of labile organic carbon which may represent organic matter produced in the water column overlying the sediment, or otherwise close to the site of deposition.

\section{Extractable Organic Matter}

Twelve samples from Site 380 were analyzed by conventional petroleum source-rock evaluation techniques. The results are summarized in Table 3 . The content of chloroform-extractable bitumen ranges from 37 to 1520 ppm by weight, or from $0.9 \%$ to $6.4 \%$ of the organic carbon. In general, the deeper calcareous and dolomitic sediments contain more organic matter than the shallower, dominantly terrigenous part of the section.
When the chloroform-extractable organic matter is fractionated on silica gel, the heptane eluate is composed predominantly of alkane and cycloalkane hydrocarbons; the benzene eluate contains aromatic hydrocarbons and, in thermally immature sediments, abundant nonhydrocarbons such as esters and alcohols; the 1:1 benzene-methanol eluate contains the most polar compounds, i.e., the asphaltic nonhydrocarbons.

Generally, the sum of the three fractions does not equal the theoretical quantity of bitumen placed on the silica-gel column, as indicated by the percentages in the last column of Table 3. This discrepancy is due to (1) the weight of unevaporated chloroform in samples with the highest bitumen concentrations, (2) a small amount of column hold-up, (3) additional evaporation losses in subsequent solvent evaporation steps. For very small samples these factors are minimal; however, column blank or hygroscopic material in the benzenemethanol fraction may cause recoveries slightly greater than $100 \%$.

The extractable organic matter from dominantly terrigenous sediment appears to contain the highest proportion of saturated hydrocarbons (heptane eluate), and the lowest proportion of asphaltics. Diatomaceous, calcareous, and dolomitic sediments contain extractable organic matter which is lower in relative amounts of saturated hydrocarbons.

There is no apparent variation in the relative amounts of the various classes of extractable organic matter with depth of burial and/or with age and temperature history.

\section{Gas Chromatography}

The detailed composition of the heptane eluate is indicated by the gas chromatograms shown in Figures 3(A-L). The hydrocarbon composition appears to be generally related to the stratigraphy, or to the composition of the organic matter deposited and preserved at different stages during the geological history of the Black Sea.

Odd-numbered $n$-alkanes in the range of $n-\mathrm{C}_{21}$ to $n$ $\mathrm{C}_{35}$ are the major constituents of the saturated hydrocarbons extracted from all samples analyzed in Holes 380/380A, except for Section 380A-53-4 at $821 \mathrm{~m}$ (Figure $3[\mathrm{I}]$ ), which is dominated by $(95 \%)$ tetracyclic and pentacyclic triterpane hydrocarbons. Samples from the shallower, dominantly terrigenous part of the section also contain appreciable amounts of mono-, di-, and tricyclic alkanes, which are expressed in the chromatogram as a hump of unresolved compounds occurring between $n-C_{14}$ and $n-C_{25}$. Samples deeper than $380 \mathrm{~A}-37-2$, which is at 667 meters, contain no appreciable $\mathrm{C}_{14}$-to- $\mathrm{C}_{25}$ cycloalkane hydrocarbon hump.

Sediment samples from depth intervals shown as diatomaceous in the general stratigraphic section (Figure 1) contain one or both of two compounds which may be biological markers characteristic of diatoms. These compounds are shown as the major peaks in th $n-\mathrm{C}_{25}$ region in Figures $3(\mathrm{~B}, \mathrm{D}, \mathrm{E}, \mathrm{H}$, and $\mathrm{I})$.

Tetracyclic and pentacyclic hydrocarbons are abundant in all of the samples from 380A-48-0 at 770 meters to the deepest sample, 380A-74-1, at 1017 meters. The appearance of significant amounts of these 
TABLE 3

Extractable Organic Matter, Black Sea Sediments, Site 380

\begin{tabular}{lcccccrr}
\hline $\begin{array}{c}\text { Sample } \\
\text { Interval in cm }\end{array}$ & Depth (m) & $\begin{array}{c}\text { Organic } \\
\text { Carbon } \\
\text { (wt \%) }\end{array}$ & $\begin{array}{c}\mathrm{CH}_{3} \text { CI-soluble } \\
\text { Bitumen } \\
\text { (wt ppm) }\end{array}$ & $\begin{array}{c}\text { Heptane } \\
\text { Eluate } \\
\text { (wt ppm) }\end{array}$ & $\begin{array}{c}\text { Benzene } \\
\text { Eluate } \\
\text { (wt ppm) }\end{array}$ & $\begin{array}{c}\text { Benzene- } \\
\text { Methanol } \\
\text { Eluate } \\
\text { (wt ppm) }\end{array}$ & $\begin{array}{c}\text { Percent } \\
\text { Recovery }\end{array}$ \\
\hline $380-0-1,126-150$ & 1 & 0.6 & 153 & 18 & 23 & 88 & 84.3 \\
$380-19-5,85-97$ & 178 & 0.8 & 206 & 14 & 24 & 141 & 86.9 \\
$380-25-3,102-113$ & 231 & 0.7 & 108 & 16 & 19 & 60 & 88.0 \\
$380 \mathrm{~A}-3-1,66-78$ & 352 & 1.0 & 210 & 11 & 31 & 141 & 87.1 \\
$380 \mathrm{~A}-14-1,67-80$ & 457 & 1.0 & 175 & 13 & 25 & 132 & 97.1 \\
$380 \mathrm{~A}-21-3,40-50$ & 526 & 0.4 & 37 & 5 & 9 & 25 & 1054 \\
$380 \mathrm{~A}-37-2,60-72$ & 667 & 0.8 & 81 & 8 & 18 & 57 & 102.5 \\
$380 \mathrm{~A}-48-0,1-12$ & 770 & 1.9 & 250 & 11 & 41 & 184 & 94.4 \\
$380 \mathrm{~A}-53-4,8-17$ & 821 & 2.0 & 1190 & 94 & 101 & 639 & 70.1 \\
$380 \mathrm{~A}-64-3,12-24$ & 925 & 2.4 & 1520 & 63 & 249 & 640 & 62.6 \\
$380 \mathrm{~A}-70-1,25-36$ & 979 & 1.1 & 175 & 14 & 30 & 105 & 85.1 \\
$380 \mathrm{~A}-74-1,89-100$ & 1017 & 1.5 & 279 & 14 & 51 & 150 & 77.1 \\
\hline
\end{tabular}

compounds roughly corresponds with a transition from dominantly terrigenous, detrital sediments to dominantly calcareous or dolomitic marls. These two sediment types probably contain different types of organic matter. The end=member composition of saturated hydrocarbons associated with these two types of organic matter may be represented by Sections 380A-21-3 and 380A-53-4 (Figures 3[F and J]).

\section{Mass Spectral Evidence for Structure of Prominent Compounds}

The compounds which occur prominently in samples from Black Sea Holes 380/380A are listed in Table 4. A discussion of polycyclic compounds follows.

Compounds $\mathrm{M}^{+} \mathbf{3 3 0}$ and $\mathrm{m}^{+} \mathbf{3 2 8}$ : These compounds are suggested as biological markers derived from organic matter deposited with diatomaceous sediments. The mass spectrum of the $\mathrm{M}+330\left(\mathrm{C}_{24} \mathrm{H}_{42}\right)$ compound indicates intense parent and $\mathrm{M}-\mathrm{CH}_{3}(\mathrm{~m} / \mathrm{e} 315)$ ions, with other major fragmentions at $\mathrm{M}-\mathrm{C}_{6} \mathrm{H}_{13}(\mathrm{~m} / \mathrm{e} 245)$, $\mathrm{m} / \mathrm{e} 191, \mathrm{~m} / \mathrm{e} \mathrm{179}$, and $\mathrm{m} / \mathrm{e} 177$ (see Figure 4). Interpretation of ions at $\mathrm{m} / \mathrm{e} 245,191$, and 179 suggests the structure shown in Figure 4. The structure of $m^{+} 328$ $\left(\mathrm{C}_{24} \mathrm{H}_{40}\right)$ and a homolog $\mathrm{M}^{+} 314\left(\mathrm{C}_{23} \mathrm{H}_{38}\right)$ isolated from the leading edge of peak $\mathrm{M}^{+} 328$ could not be determined from their mass spectra, shown in Figures 5 and 6 , respectively.

Compounds $\mathbf{M}^{+} \mathbf{3 7 2}$ and $\mathbf{M}^{+} \mathbf{3 7 0}$ : The $\mathrm{M}^{+} 372\left(\mathrm{C}_{27} \mathrm{H}_{48}\right)$ compound has the fragmentation pattern of $5 \propto$ cholestane with typical sterane fragment ions at $\mathrm{m} / \mathrm{e}$ $149,163,177,217$, and 218 . The $\mathrm{M}^{+} 370\left(\mathrm{C}_{27} \mathrm{H}_{46}\right)$ peak represents at least two geometric isomers having mass spectral fragmentation patterns (Figure 7) characteristic of $\mathrm{C}_{27}$ sterenes (Rubinstein et al., 1975; $\mathrm{R}$ head et al., 1971). The leading edge of the peak gives $\mathrm{M}+370$ (100\%), $355\left(38 \%, \mathrm{M}-\mathrm{CH}_{3}\right), 257$ (83\% M-side chain from C-17), and 215 (40\%, cleavage of D ring at bonds 13-17 and 14-15). The top of the GC peak gives the following mass spectral characteristics: $M+370$ (100\%), $355\left(40 \%, \mathrm{M}-\mathrm{CH}_{3}\right), 257$ (50\%, M-side chain from C-17), and 215 (97\% M-cleavage of D ring at bonds 13-17 and 14-15). The mass spectral fragmentation pattern of the latter $M^{+} 370$ peak resembles somewhat the cholest-5-ene spectrum described by Rhead et al., (1971); except that the m/e
275 and 301 ions are less intense in the Black Sea samples.

Compound $\mathrm{M}^{+}$384: The GC-MS peak corresponding to $\mathrm{M}^{+} 384\left(\mathrm{C}_{28} \mathrm{H}_{48}\right)$ is a pentacyclic triterpane of the degraded moretane-lupane-hopane variety. The mass spectrum is shown in Figure 8. Cleavage of the 9-11 and 8-14 bonds gives the $\mathrm{m} / \mathrm{e} 191$ ion. Cleavage of the 12-13 and 8-14 bonds gives the m/e 163 ion. Ethyl loss at M29 is also seen. The absence of an M-43 ion and a major fragment ion corresponding to cleavage of a fivemembered ring at bonds $18-19$ and $17-21$ suggests that ring $\mathrm{E}$ is of the type group $8 \mathrm{~b}$ described by Kimble et al., (1974).

Compound $\mathrm{M}^{+} 398$ (sterene): Fragmentation characteristics of the $\mathrm{M}^{+} 398\left(\mathrm{C}_{29} \mathrm{H}_{50}\right)$ compound shown in Figure 9 suggest a $\mathrm{C}_{29}$ sterene (Steel and Henderson, 1972). This compound appears as a small peak on the front edge of the $M^{+}+10$ peak in Sample 380A-53-4 (Figure 3[I]) and as a major peak in Sections 380A-64-3 (Figure 3[J]), 380A-70-1 (Figure 3[K]), and 380A-74-1 (Figure 3[L]). Key diagnostic fragment ions for this GC peak are $\mathrm{M}^{+} 398(64 \%), 383\left(35 \%, \mathrm{M}-\mathrm{CH}_{3}\right), 257(51 \%$, $\mathrm{M}-\mathrm{C}_{10} \mathrm{H}_{21}$ from cleavage of side chain at $\left.\mathrm{C}-17\right), 215$ (100\% M-cleavage of D ring at bonds 13-17 and 14-15), $149(66 \%)$, and $147(86 \%)$. If this compound is derived from a dehydrated $\mathrm{C}_{29}$ sterol, such as B-sistosterol or stigmastanol, the double bond is probably in the 5-6 position, unless rearrangement has taken place. The suggested structure is conjecture at this point.

Compound $M^{+} \mathbf{4 1 0}$ (pentacyclic triterpene): The principal mass spectral fragment ions (Figure 10) for the GC-MS, $\mathrm{M}+410\left(\mathrm{C}_{30} \mathrm{H}_{50}\right)$ peak (Figure $3[\mathrm{I}]$ ) are as follows: $\mathrm{M}^{+} 410(20 \%), 367\left(36 \%, \mathrm{M}-\mathrm{C}_{3} \mathrm{H}_{7}\right), 231(41 \%)$, $191(73 \%), 189$ (38\%), 177 (18\%), $175(31 \%), 163(23 \%)$, $161(59 \%), 149(19 \%), 147(22 \%), 137(46 \%)$, and 135 $(100 \%)$. The ion pairs at $\mathrm{m} / \mathrm{e} 191-189,177-175,163-161$, and 149-147, and the ions m/e 107, 121, and 135 suggest an unsaturated pentacyclic triterpenoid. The only natural pentacyclic triterpenoids showing a $\mathrm{C}_{3} \mathrm{H}_{7}$ loss contain an isopropyl group attached to a fivemembered ring. Also, the only $\mathrm{C}_{30}$ pentacyclic triterpenoids showing no cleavage of their five-membered ring are of the lupane-hopane variety (Kimble et al., 1974). The m/e 189 and 191 ion pair, with the 191 ion double the intensity of the 189 ion, suggests a non- 


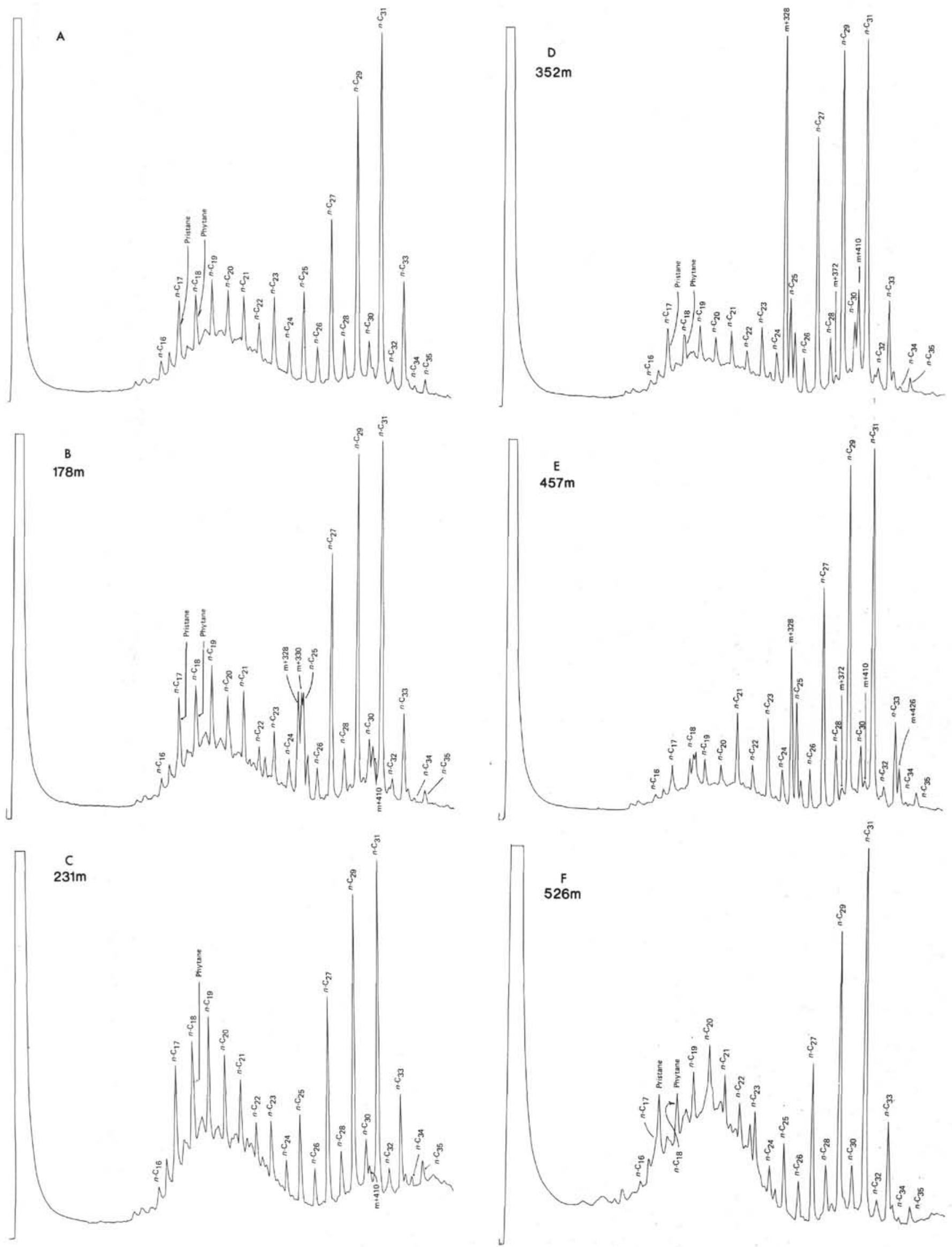

Figure 3A-F. Gas chromatigraphic analysis of saturated hydrocarbons from Hole 380/380A sediments. 
D. E. ANDERS, G. E. CLAYPOOL, C. M. LUBECK, J. M. PATTERSON
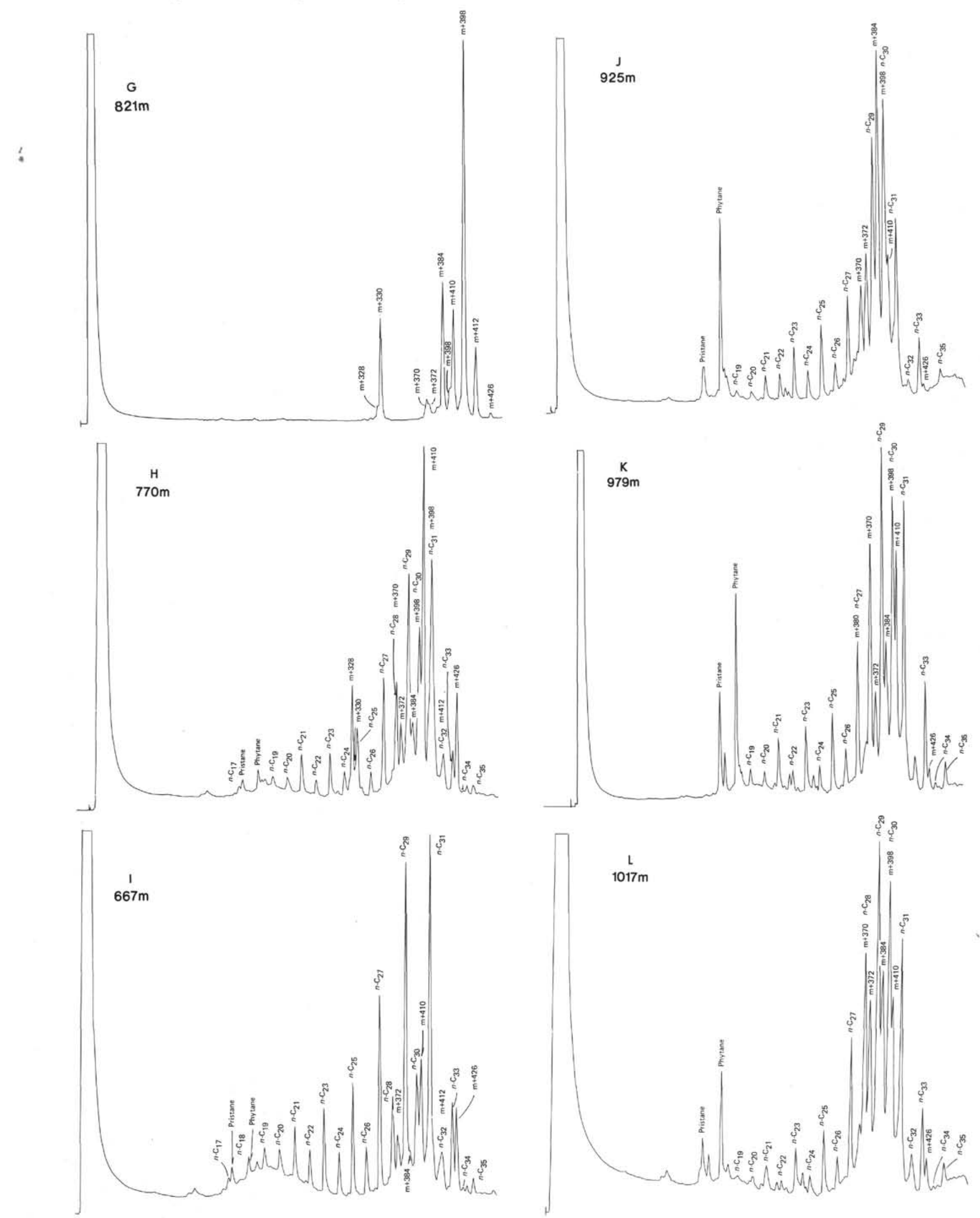

Figure 3G-L. Gas chromatigraphic analysis of saturated hydrocarbons from Hole 380/380A sediments. 
TABLE 4

Occurrence of Major Gas Chromatographic Peaks Examined by Mass Spectrometry in Black Sea Samples

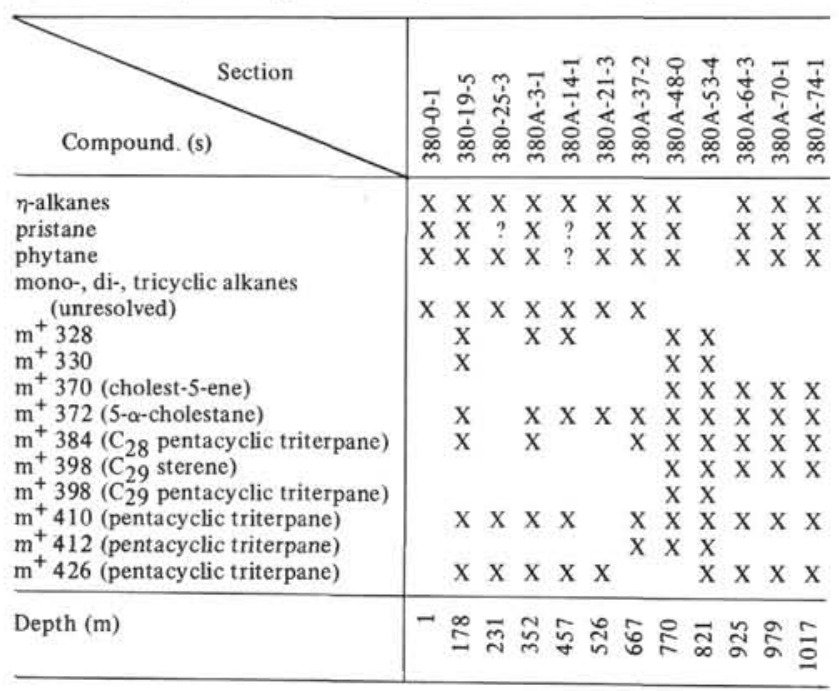

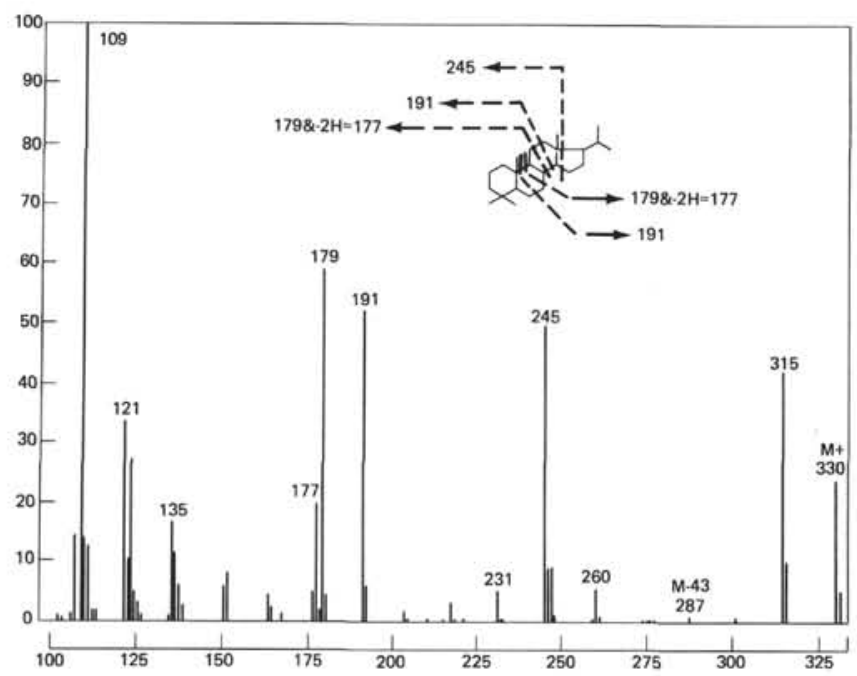

Figure 4. Mass spectra of compound $M^{+} 330$.

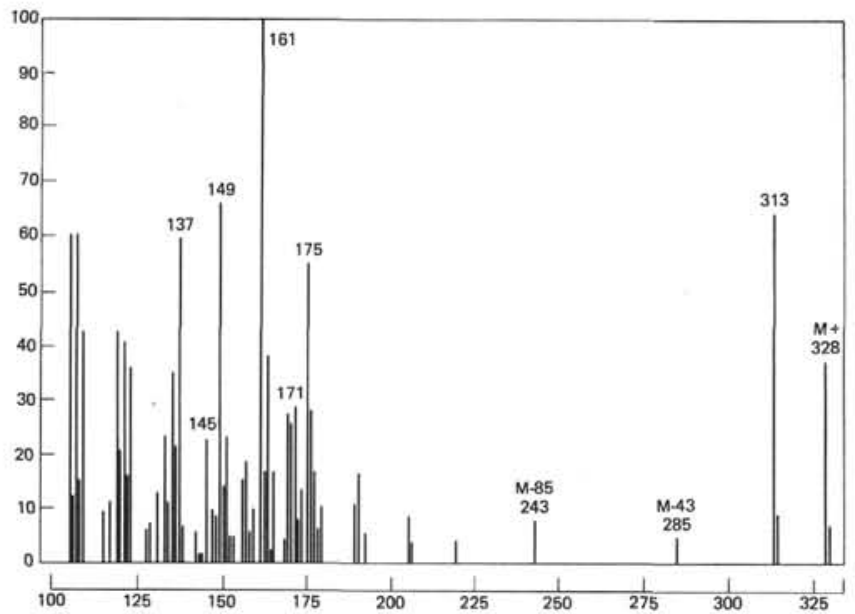

Figure 5. Mass spectra of compound $M^{+} 328$.

symmetrical nucleus. The more intense 191 ion probably results from the D and E ring fragment (Kimble et al., 1974). The presence of intense ions at 79,

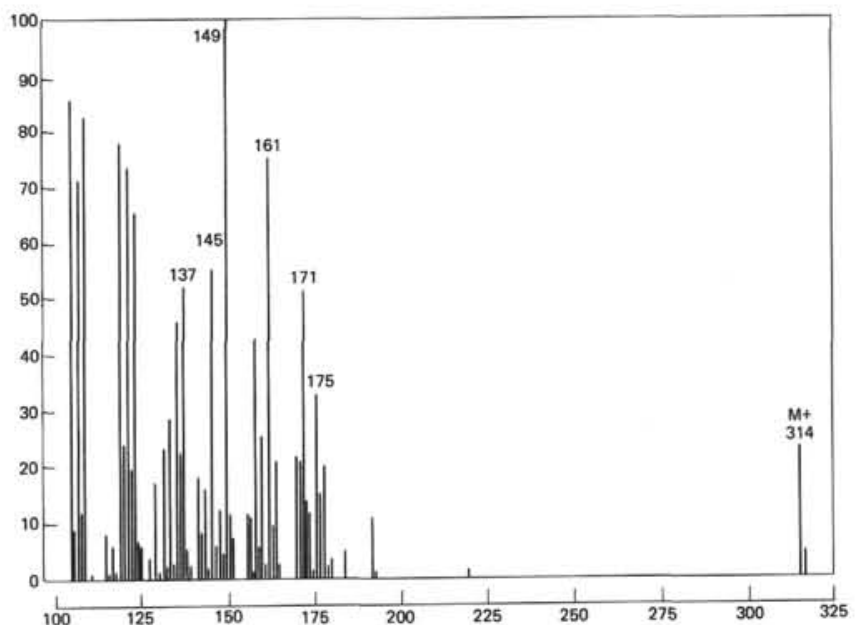

Figure 6. Mass spectra of compound $M^{+} 314$.

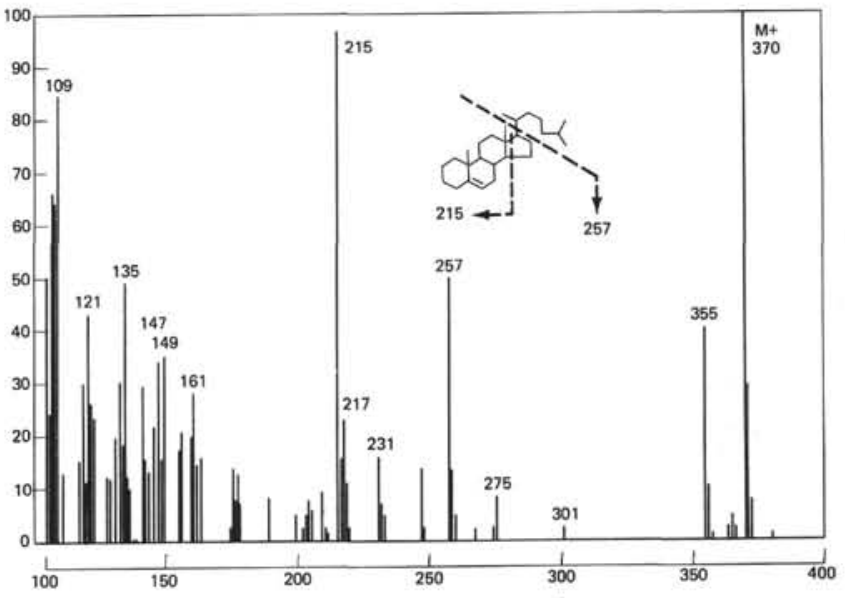

Figure 7. Mass spectra of compound $M^{+} 370$.

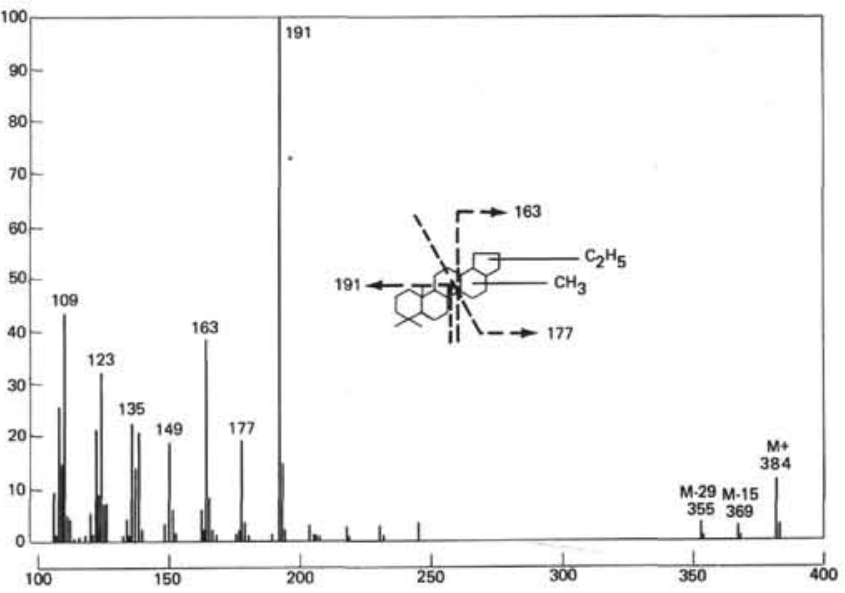

Figure 8. Mass spectra of compound $M^{+} 384$.

$93,107,121$, and 135 , lead us to believe that the double bonds resides in ring A. Again, without an authentic sample for comparison, any suggested structure is conjecture.

Compound $\mathrm{M}^{+} 398$ (pentacyclic): The $\mathrm{M}^{+} 398\left(\mathrm{C}_{29} \mathrm{H}_{50}\right)$ compound eluting as the major component in Section $380 \mathrm{~A}-53-4$ (Figure $3[\mathrm{I}]$ ) is probably of the degraded oleanane-gammacerane (Figure 11) variety containing 


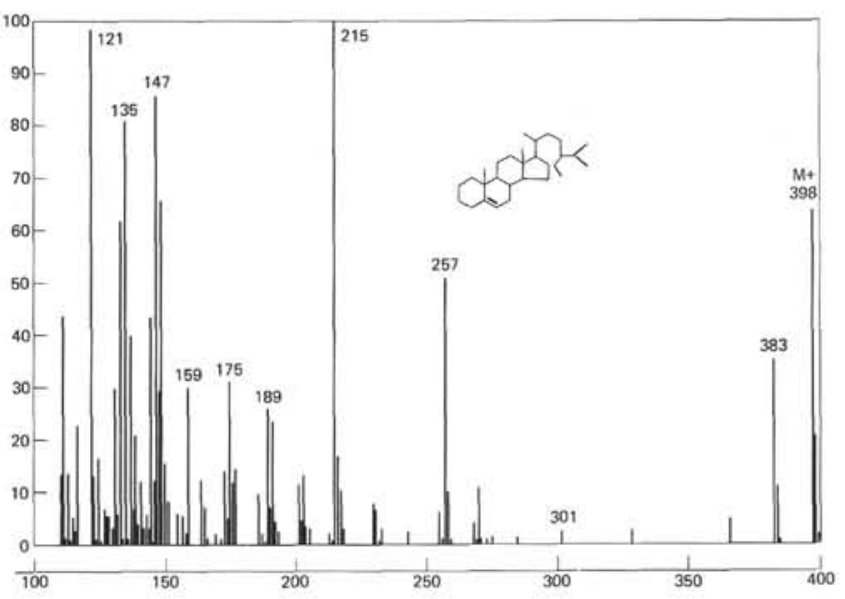

Figure 9. Mass spectra of compound $M^{+} 398$ (sterene).

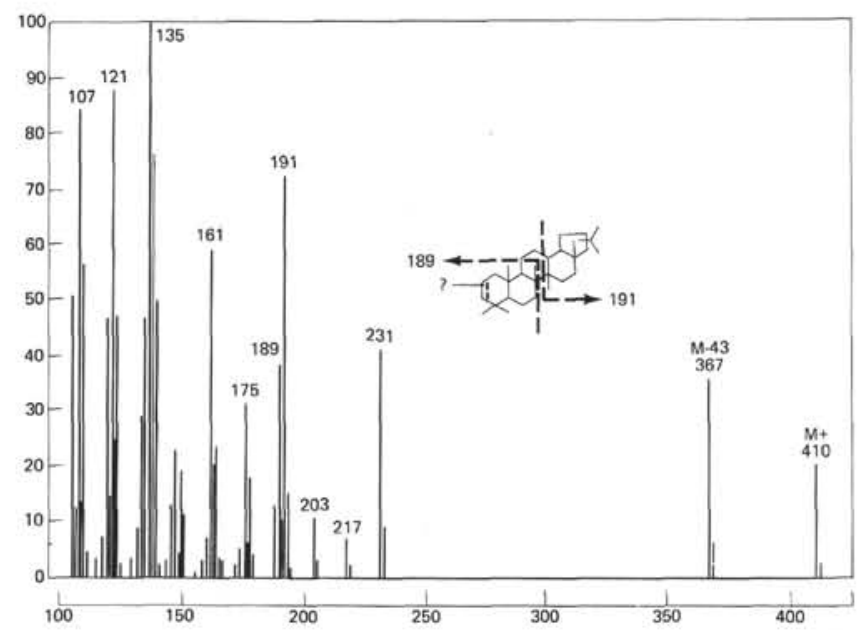

Figure 10. Mass spectra of compound $M^{+} 410$.

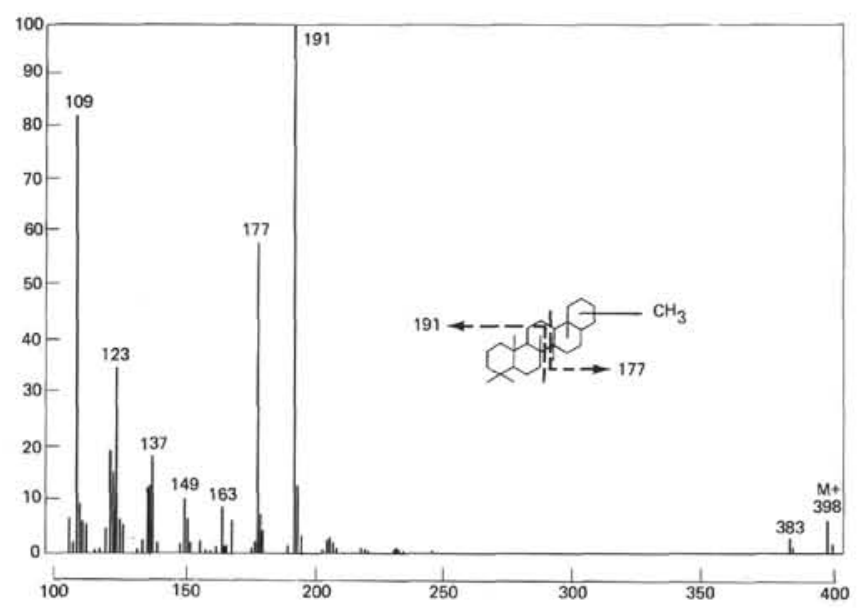

Figure 11. Mass spectra of compound $\mathrm{M}^{+} 398$ (pentacyclic).

five six $=$ membered rings, two of which have the A-B ring configuration (giving the intense $\mathrm{m} / \mathrm{e} 191$ ion) and two of which have the D-E ring configuration minus one methyl substituent (giving the $\mathrm{m} / \mathrm{e} 177$ ion). No fragment ions were seen to suggest a five-member ring (i.e., $\mathrm{m} / \mathrm{e}$ 327) or a side chain larger than methyl. The mass spectrum resembles the $\mathrm{C}_{29} \mathrm{H}_{50}$ pentacyclic triterpenoid isolated by Gallegos (1971) from Green River shale.

Compound $\mathrm{M}^{+}$412: Mass spectral fragmentation of the $\mathrm{M}^{+} 412\left(\mathrm{C}_{30} \mathrm{H}_{52}\right)$ compound (Figure 12) in Section 380A-53-4 (Figure 3[I]) suggests a structure similar to the Adianane variety of pentacyclic triterpenoids (Kimble et al., 1974). Fragmentation producing the $\mathrm{m} / \mathrm{e} 179$ and $\mathrm{m} / \mathrm{e} 191$ cleavage products in Adianane type triterpanes appears to be controlled by the substituents at $\mathrm{C}-13$ and $\mathrm{C}-14$. The $\mathrm{m} / \mathrm{e} 327$ ion results from cleavage of the 1819 and $17-21$ bonds of the five-member ring. The $\mathrm{m} / \mathrm{e}$ 259 ion comes from cleavage of the 13-18 and 14-15 bonds of ring $\mathrm{D}$.

Compound $\mathrm{M}^{+}$426: The $\mathrm{M}+426\left(\mathrm{C}_{31} \mathrm{H}_{54}\right)$ compound in Sample 380A-53-4 is resolved by gas chromatography (Figure 3[I3); however, it is also present in every sample throughout the core. Its mass spectrum, shown in Figure 13, appears to be similar to the pentacyclic triterpane, Homomoretane, isolated by Anders and Robinson (1971) from Green River shale. For a discussion of fragmentation routes of such compounds, with extended chains, see Kimble et al., (1974).

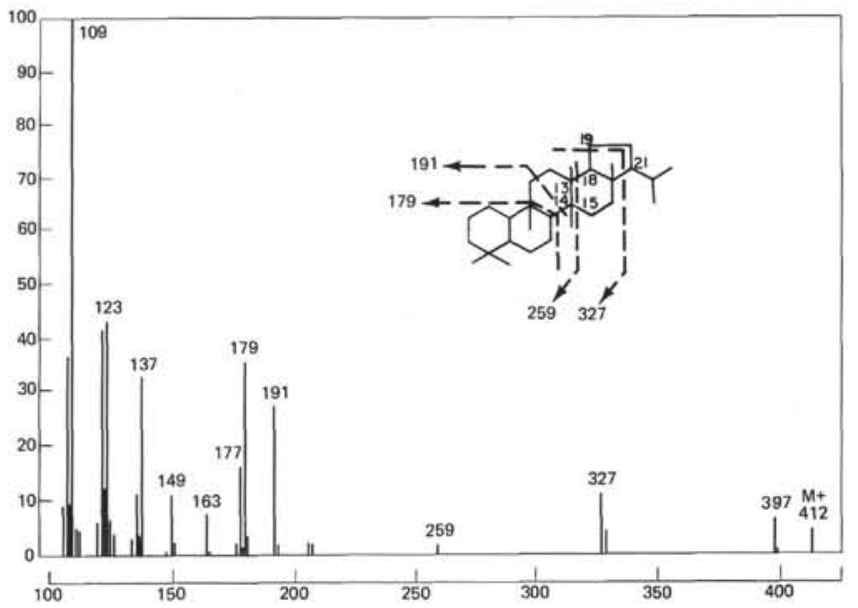

Figure 12. Mass spectra of compound $M^{+} 412$.

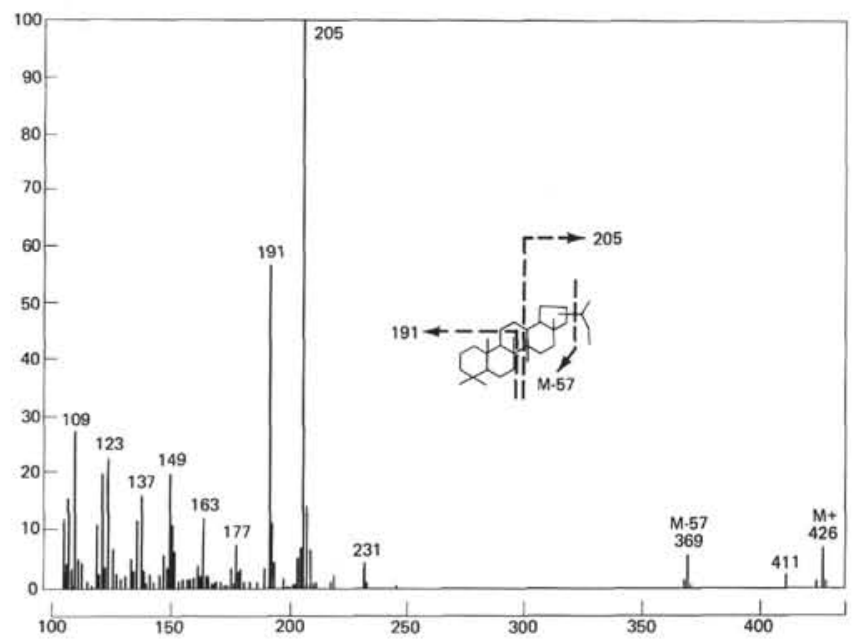

Figure 13. Mass spectra of compound $M^{+} 426$. 


\section{GENERAL OBSERVATIONS}

The Black Sea sediments penetrated in Holes $380 / 380 \mathrm{~A}$ are of dominantly terrigenous origin in the upper part of the section, while the lower part of the section contains abundant dolomitic marls. The hydrocarbons extracted from the sediments may reflect, in a similar way, provenance or origin of the organic matter. In the upper part of the section $n$-alkanes are the predominant hydrocarbon constituents, while in the lower part of the section steranes (and sterenes) and pentacyclic triterpanes (and triterpenes) are major constituents, although $n$-alkanes are usually important throughout the section. There is no clear evidence for thermal diagenetic effects in the heavy hydrocarbon fraction of these samples. The organic matter in the upper part of the section may be predominantly that which has washed in with the terrigenous sediment, i.e., an allochthonous component which is resistant to oxidative decomposition during sedimentary transport, such as higher plant tissues. In the lower part of the section, a major component of the organic matter preserved in the sediments may be that which is produced at the site of deposition (i.e., an autochthonous component), which would tend to be better preserved during carbonate-depositing phases of the Black Sea lake.

The terrigenous allochthonous component is characterized by a saturated hydrocarbon assemblage of predominantly odd-numbered $n$-alkanes with maxima at $n-\mathrm{C}_{31}$, and by $1-, 2-$, and 3-ring cycloalkanes. The hydrocarbon assemblage of the lacustrine, autochthonous component appears to be uniquely characterized by the presence of $\mathrm{C}_{27}$ and $\mathrm{C}_{29}$ sterenes, and by the absence of 1-, 2-, and 3-ring cycloalkanes. In addition, pristane, phytane, and a variety of tetracyclic and pentacyclic hydrocarbons are present at concentration levels greater than or subequal to those of the $n$-alkanes. The samples in Holes 380/380A from depths of 1 to 526 meters contain predominantly allochthonous organic matter, while the samples from 770 to 1017 meters contain mostly autochthonous organic material. The sample at 667 meters appears to be transitional.

The average organic carbon content of the seven shallowest samples in Holes $380 / 380 \mathrm{~A}$ is $0.9 \%$, while it is $1.8 \%$ for the five deepest samples. Moreover, the yield of pyrolytic hydrocarbons is $0.03 \%$ to $0.08 \%$ for the shallow interval containing the allochthonous organic matter, and $0.20 \%$ to $0.97 \%$ for the deeper interval containing the autochthonous organic matter. The result is that the average yield of pyrolytic hydrocarbons per unit of organic carbon is about four times higher for organic matter in the deeper part of the section. These differences illustrate the importance of the environment of deposition to the generation of hydrocarbons; apparently the type of organic matter preserved during carbonate deposition has a greater capacity to form hydrocarbons.

Although the organic matter is very well preserved in these cores, it is not present in unusually high concentrations. This is most likely due to the extremely rapid sedimentation rate and consequent dilution of the organic matter by noncarbonaceous, but possibly biogenic, sedimentary constituents. Thus, while the Black Sea sediments are in many respects qualitatively similar to Green River oil shale, they have only about one-tenth of the organic matter content of economically important oil shales.

\section{ACKNOWLEDGMENTS}

This manuscript was reviewed by Robert E. Miller, U.S. Geological Survey, Reston, Virginia.

\section{REFERENCES}

Anders, D.E. and Robinson, W.E., 1971. Cycloalkane constituents of the bitumen from Green River Shale: Geochim. Cosmochim. Acta, v. 35, p. 661-678.

Claypool, G.E. and Reed, P.R., 1976. Thermal-analysis technique for source-rock evaluation: quantitative estimate of organic richness and effects of lithologic variation: Am. Assoc. Petrol. Geol. Bull., v. 60, p. 608611.

Gallegos, E.J., 1971. Ide2tification of new sterones, triterpanes and branched paraffins in Green River Shale by capillary chromatography and mass spectrometry: Anal. Chem., v. 43, p. 1151-1161.

Kimble, B.J., Maxwell, J.R., Philp, R.P., and Eglinton, G., 1974. Identification of steranes and triterpanes in geoliped extracts by high-resolution gas chromatography and mass spectrometry: Chem. Geol., v. 14, p. 173-198.

Rhead, M.M., Eglinton, G., and Draffan, G.H., 1971. Hydrocarbons produced by the thermal alteration of cholesterol under conditions simulating the maturation of sediments: Chem. Geol., v. 8, p. 277-297.

Rubinstein, I., Sieskind, O., and Albrecht, P., 1975. Rearranged sterenes in a shale: occurrence and simulated formation: J. Chem. Socl, p. 1833-1836.

Steel, G. and Henderson, W., 1972. Isolation and characterization of stanols from Green River Shale: Nature, v. 238 , p. $148-149$. 